\title{
Patterns of distribution of marine assemblages from rocky shores: evidence of relevant scales of variation
}

\author{
Simonetta Fraschetti ${ }^{1, *}$, Antonio Terlizzi ${ }^{1}$, Lisandro Benedetti-Cecchi ${ }^{2}$ \\ ${ }^{1}$ Laboratorio Zoologia e Biologia Marina, Dipartimento di Scienze e Tecnologie Biologiche ed Ambientali, \\ Università di Lecce, CoNISMa, 73100 Lecce, Italy \\ ${ }^{2}$ Dipartimento di Scienze dell'Uomo e dell'Ambiente, Università di Pisa, CoNISMa, Via A. Volta 6, 56126 Pisa, Italy
}

\begin{abstract}
Increasing evidence indicates that spatial and temporal patterns in ecological systems are not independent of the scale of measurement. In this study we used a hierarchical sampling design to examine spatial patterns in assemblages of algae and invertebrates in midshore and lowshore habitats of rocky coasts in the Mediterranean Sea, increasing the range of scales usually covered by this type of study in marine habitats. To put our results in a broader context, we also conducted a review of the literature, targeting studies that explicitly investigated spatial patterns with hierarchical designs. We addressed 2 main questions: (1) To what extent does small-scale variability contribute to large-scale patterns of variation? (2) Is there a pattern of variability that can be generalised across species and habitats? The review of the literature indicated that hierarchical analyses of spatial pattern have been limited to a narrow range of habitats and taxa and that very few studies have addressed regional scales of variation (1000s of kilometers). The available data, however, did identify a general pattern: variability was larger at small spatial scales (meters) in almost all habitats, whereas variation over larger spatial scales (10s to 100s of kilometers) depended on the specific habitat and taxa examined. In our case study, we obtained measures of spatial variability through the use of 2 alternative methods: hierarchical nested design and independent estimate of spatial variance between pairs of quadrats. Both approaches provided further support to the patterns displayed by the analysis of the literature. Most response variables exhibited large variation over small spatial scales, while the significance of mid- to large-scale variability differed between midshore and lowshore habitats and among taxa. Although a proper understanding of large-scale patterns will require additional comparisons across wide geographical areas, small-scale variability emerges as a general property of benthic assemblages in marine coastal habitats. We suggest that this pattern is common to a wide range of natural systems where assemblages are influenced by complex sets of physical and biological processes like those operating in the marine environment.
\end{abstract}

KEY WORDS: Spatial scale · Patchiness · Hierarchical ANOVA · Spatial variance · Rocky shores · Algae $\cdot$ Invertebrates

\section{INTRODUCTION}

The complexity of many ecological systems, underlying physical and biological heterogeneity at different spatial scales, is influencing the way ecologists view populations, communities and ecosystems (Holling 1992, Levin 1992). The appreciation of scale-dependent patterns is not a novelty; what is innovative is the recent expanded application of the concept in the design and interpretation of surveys, comparative studies and controlled experiments (Schneider 1994, Brown 1995, Maurer 1999). In terrestrial systems, the dependence of spatial patterns at different scales was first investigated in agricultural experiments (Mercer \& Hall 1911). Different disciplines (from landscape ecology to geography) have contributed to generate new understanding of scale-dependent patterns and processes in physical and biological variables (Dungan et 
al. 2002). The development of novel technical tools enabling the analysis of spatial patterns of populations over very small $\left(\sim 10^{-3} \mathrm{~m}\right)$ to very large $\left(\sim 10^{5} \mathrm{~m}\right)$ spatial scales and the refinement of statistical techniques for the analysis of such data have enhanced researchers' capacity to investigate a broad range of natural phenomena (Perry et al. 2002).

The analysis of spatial patterns of biodiversity in coastal marine systems has received wide attention, but the small size and cryptic nature of many marine organisms has prevented the broad use of recent technological innovations (e.g. remote sensing) in largescale sampling. This has constrained the range of scales addressed by marine studies, which is usually smaller than that addressed by the terrestrial counterparts (but see Connolly \& Roughgarden 1998, Broitman et al. 2001). Analyses in marine coastal systems have, however, highlighted common patterns of small(10s to 100 s of centimeters) to middle-scale (10s to $100 \mathrm{~s}$ of meters) variation in the distribution and abundance of populations across a wide range of habitats and organisms (Foster 1990, Underwood \& Chapman 1996, Menconi et al. 1999, Underwood et al. 2000, BenedettiCecchi 2001a, Kelaher et al. 2001, Olabarria \& Chapman 2001). The general picture emerging from these studies is that small-scale processes are at least as important as large-scale processes in generating patterns in benthic assemblages and that small-scale spatial variance should not be considered simply as a statistical nuisance (Thrush et al. 1994, Horne \& Schneider 1995, Coleman 2002).

Some evidence supports the view that local processes may scale up to generate large-scale patterns, suggesting that detailed studies at local scales are important to understand variation at the regional scale (Thrush et al. 1997a,b, Wootton 2001, Irving et al. 2004). Changes in small-scale spatial patterns are also used to assess potential symptoms of stress in marine assemblages (Warwick \& Clarke 1993, Chapman et al. 1995, Fraschetti et al. 2001, Terlizzi et al. 2002) and recent advancements in statistical analysis allow a better quantification of small-scale patchiness, both in the univariate and multivariate contexts (Underwood \& Chapman 1996, 1998a,b, Legendre \& Anderson 1999, Terlizzi et al. 2005).

Although coastal habitats, such as intertidal and shallow subtidal environments, have proved to be tractable systems for analyses of spatial patterns in populations and assemblages (Archambault \& Bourget 1996, Underwood \& Chapman 1998a,b, BenedettiCecchi 2001a, Menge \& Branch 2001, Fowler-Walker \& Connell 2002, Fraschetti et al. 2002, Thompson et al. 2002), most studies have focused on a narrow range of spatial scales in a limited number of habitats (see 'Results: Review of the literature').
Investigating the influence of regional processes on populations and assemblages and determining the extent to which small-scale processes can be generalised, does require large-scale investigations (Lawton 1996). Few studies, however, have examined spatial variability over large scales (1000s of kilometers) in marine organisms (but see Åberg \& Pavia 1997, Jenkins et al. 2000, 2001, Fowler-Walker \& Connell 2002, Irving et al. 2004, Kelaher et al. 2004). The results of these investigations are somewhat contrasting, revealing little to no variability over regional scales in some instances and large variability in others. The extent to which the amount of small-scale variability compares to large-scale variation remains largely unexplored.

We address these issues in 2 ways: (1) through a review of the literature on the analysis of spatial patterns in marine habitats to document major achievements and possible gaps of knowledge on this topic, and (2) with a detailed study on spatial patterns in assemblages of midshore and lowshore habitats of rocky coasts in the Mediterranean. This analysis included 4 spatial scales, ranging from quadrats 10 s of centimeters apart up to the regional scale, covering a spatial extent of more than $1000 \mathrm{~km}$. We used a nested sampling design to test the null hypothesis that spatial pattern is invariant to scale in both habitats. Rejection of this hypothesis would lead to the identification of 1 or more relevant scales of spatial variation, providing clues on possible important processes for these assemblages.

Nested sampling designs in association with hierarchical analysis of variance are a powerful tool to investigate spatial (or temporal) patterns across scales. This approach, however, is not completely free of problems, as discussed in the recent literature (Palmer 1988, Rossi et al. 1992, Underwood \& Chapman 1996, 1998a, Benedetti-Cecchi 2001a). A main issue in applying a hierarchical analysis of variance to a nested design is that intensity of sampling and therefore statistical power increases lower in the hierarchy. This prevents a direct comparison of the magnitude of variability at different scales (see Underwood \& Petraitis 1993, Underwood \& Chapman 1998a, Benedetti-Cecchi 2001a for further details).

To address these issues, spatial patterns in populations and assemblages were also compared using variances (or their multivariate analogues) between pairs of replicate units so that intensity of sampling was constant across scales.

\section{MATERIALS AND METHODS}

Review of the literature. We reviewed 39 studies reporting on analysis of spatial patterns in marine coastal habitats. These studies were selected by using 
the 'Science Citation Index Expanded Database' on a web research platform (ISI Web of Science). The research was restricted to papers in English published from 1990 to 2004 and explicitly referring to the terms 'scale(s)' and/or 'spatial' (in association with the terms 'heterogeneity', 'pattern[s]', 'variability', 'variation') in the title, keywords and/or abstract. A variety of approaches have been used to quantify spatial variability in populations and assemblages (Rossi et al. 1992). Herein, we devoted attention to papers that explicitly used hierarchical sampling designs.

The review focused on vagile and sessile invertebrates and macroalgae that are common in marine coastal habitats. The following data were extracted from each study and synthesised in a table: targeted habitats (e.g. intertidal, subtidal), geographical areas of investigation, response variables (e.g. percentage cover, number of individuals, structure of assemblage), statistical procedures utilised to examine spatial patterns (i.e. uni- or multivariate analyses), the range of scales included and the main results (i.e. the relevant scales of variation, if any).

Study region and sampling design. Sampling was conducted in 2 regions, the Apulian coast of Italy and the Ionian coast of Greece, in late June 2001 (Fig. 1). The 2 stretches of coast occupy opposite sides of the south Adriatic Sea and fall between latitudes $41^{\circ} 57^{\prime}$ and $37^{\circ} 55^{\prime} \mathrm{N}$, more than $1000 \mathrm{~km}$ apart. In each re-

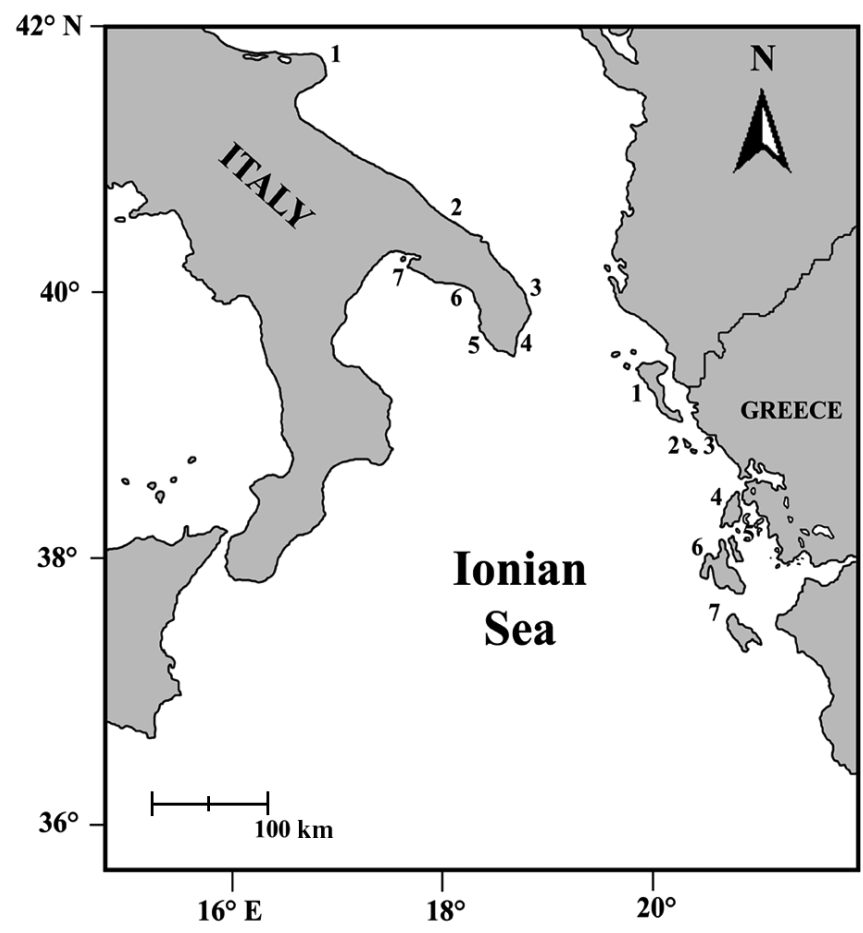

Fig. 1. Coasts of Italy and Greece. 1 to 7 : sampling locations in each region gion, 7 wave-exposed locations, separated by 10 s to 100s of kilometers, were selected at random from a set of possible locations, characterised by relatively pristine habitats and comparable in terms of type and slope of the substratum. Due to the morphology of the coastline, the distance between 2 locations within a region was occasionally larger than the distance between 2 locations of different regions (Fig. 1). At each location, 4 sites (separated by 100s to 1000 s of meters) were selected by moving at random distances from a point along the coast designated as the starting point of the location. Distances were selected using tables of random digits. At each of the 56 sites, 2 habitats were sampled, 1 at midshore heights (0.2 to $0.4 \mathrm{~m}$ above mean-low-level-water) and the other at lowshore heights (-0.1 to $0.1 \mathrm{~m}$ across mean-low-levelwater) of the coast, with five $20 \times 20 \mathrm{~cm}$ random quadrats in each habitat.

The midshore habitat was largely dominated by herbivores (Patella spp.) and encrusting algae. The lowshore habitat was characterised by dense stands of the brown algae Cystoseira spp., which is a canopy-forming group of species. These 2 habitats were selected on the basis of their accessibility, allowing sampling across a vast area $(1000 \mathrm{~km})$. The 2 habitats also enabled analyses of spatial patterns in very different assemblages along the emersion gradient of the shore.

Sampling methods. The percentage cover of sessile organisms was estimated in each quadrat by visual inspection. This was achieved by dividing the quadrat into 25 subquadrats of $4 \times 4 \mathrm{~cm}$; the abundance of each taxon was then assessed by giving a score from 0 to 4 to each subquadrat and adding up these values over the 25 subquadrats. Final values were expressed as percentages (Meese \& Tomich 1992, Dethier et al. 1993). The abundance of some mobile invertebrates and of sea anemones in each quadrat was assessed as counts. Quadrats in the lowshore habitat were sampled by assessing the cover of Cystoseira spp. initially and then by quantifying the abundance of understorey organisms after removing the canopy from the substratum. Small and fast-moving animals such as amphipods and polychaetes were not considered. Destructive samples were also collected to aid the identification of taxa in the laboratory. Specialists assisted in the taxonomic identification of organisms.

Statistical analyses. Nested analyses: Spatial patterns of total number of taxa, total cover as well as cover of particularly abundant taxa were examined by a 3-way nested analysis of variance (ANOVA), with site nested in location and location nested in region. All factors were random. Variance components were estimated for each source of variation in ANOVAs by equating observed and expected mean squares (Winer 
et al. 1991, Searle et al. 1992). Occasionally, negative estimates were obtained from the analysis. In these cases, negative values were set to zero, the corresponding factor removed from the model, and the estimates for the remaining factors re-calculated (Fletcher \& Underwood 2002). All the analyses were done on untransformed data to provide variance components comparable across all data. Prior to analysis, Cochran's $C$-test was employed to assess homogeneity of variances. The more stringent criterion of $\alpha=0.01$ was used to reject null hypotheses when variances were heterogeneous (Underwood 1997). When appropriate, Student-Newman-Keuls (SNK) tests were used for multiple comparisons of the means (at $\alpha=0.05$ ). All the univariate analyses were done using the GMAV5 programme (University of Sydney, Australia).

Permutational multivariate analysis of variance (PERMANOVA; Anderson 2001a) was used to examine spatial variation in assemblages in the 2 habitats. The analyses were based on Bray-Curtis dissimilarities (Bray \& Curtis 1957) on untransformed data (18 taxa for the midshore habitat and 54 for the lowshore habitat). Each term in the analyses was tested using 999 random permutations of the appropriate units (Anderson 2001b, Anderson \& ter Braak 2003). The analyses were carried out using the FORTRAN program PERMANOVA (Anderson 2005). Since PERMANOVA allows the partitioning of the total variation in a way analogous to that performed by ANOVA, resulting mean squares were equated to the expected mean squares to estimate pseudo-variance components in the multivariate context (e.g. Benedetti-Cecchi 2001a).

For each habitat, non-metric multidimensional scaling ordinations (nMDS) (e.g. Kruskal \& Wish 1978) were done on the basis of a Bray-Curtis dissimilarity matrix calculated from untransformed data. Ordinations were obtained by plotting the centroids of the 14 location cells to limit the number of observation points within plots. The arithmetic average across original variables does not correspond to the 'central location' in multivariate Bray-Curtis space (Anderson 2001a). Thus, to obtain centroids, principal coordinates were first calculated from the Bray-Curtis dissimilarity matrices among all pairs of the 280 quadrats and the arithmetic mean of these coordinates was then calculated. This was legitimate because the principal coordinate analysis places the observations into Euclidean space while preserving the Bray-Curtis distances among objects. The Euclidean distance between each pair of centroids was then calculated and used as the input distance matrix for the nMDS algorithm (e.g. Anderson 2001a).

As an example of small-scale variability in structure of assemblages in each habitat, data from a single location were analysed separately and the individual repli- cates of the 4 sites of that location were plotted in an nMDS.

Pairwise comparisons: An alternative method (Underwood \& Chapman 1998b) was used in order to maintain the intensity of sampling constant across scales and to obtain independent estimate of spatial variation at each scale. The data set was the same used in the previous analysis, besides the random selection of 6 out of the 7 locations available in each region to balance the data set. Data from midshore and lowshore habitats were analysed separately in this case also. The 5 quadrats available in each site and habitat were allocated randomly to 4 conditions that corresponded to contrasts of spatial variability at different scales. The first contrast used 2 of the 5 quadrats and provided a measure of spatial variability within the site. A third quadrat was contrasted with a quadrat of another site within the same location to yield a measure of variability between quadrats within a site plus the variability among sites. A fourth quadrat was contrasted with a quadrat from another site in a different location within the same region to measure the variability due to quadrats, sites and location. Finally, a fifth quadrat was paired with a quadrat from another region to measure the variability due to quadrats, sites, locations and regions. This procedure yielded 48 contrasts among quadrats within the same site and 24 contrasts at each of the other scales. To balance the data set, 24 of the 48 small-scale comparisons were selected randomly and used in analyses.

For univariate analyses, spatial variation was quantified as the variance between pairs of quadrats. For multivariate analyses, variability between pairs of quadrats was first measured as Bray-Curtis dissimilarities and then expressed as Euclidean distances following the procedure described for displaying the centroids of locations in nMDS plots (see previous subsection). Both univariate and multivariate measures of spatial variation were then compared across 4 scales (quadrat, quadrat + site, quadrat + site + location and quadrat + site + location + region) using a 1-way ANOVA with $\mathrm{n}=24$ observations in each level. SNK tests were used for multiple comparisons of the means (at $\alpha=0.05$ ) allowing a test of the null hypothesis that spatial variation was invariant to scale.

\section{RESULTS}

\section{Review of the literature}

The analysis of the literature indicated that hierarchical analyses of spatial patterns in populations and assemblages were limited to a small number of habi- 
tats and geographic areas, to few organisms and assemblages, and rarely covered spatial scales larger than 100s of kilometers. Furthermore, most studies took place in Australia, the North Atlantic region and the Mediterranean Sea. Few papers covered other geographical areas such as the Arctic (Lindegarth et al. 1995), Antarctic (Stark et al. 2003), South America (Uruguay, Giménez \& Yannicelli 2000) or Central America (Belize; Farnsworth \& Ellison 1996). The larger number of studies conducted in temperate areas was probably unrelated to particularly favorable environmental conditions for field work, since even tropical areas have not been investigated in detail for this specific topic (but see Farnsworth \& Ellison 1996, Hughes et al. 1999). Moreover, most papers focused on rocky intertidal habitats. The distributional patterns of both populations and assemblages of intertidal soft bottoms have been explored to a smaller extent than those of hard bottoms (Lindegarth et al. 1995, Thrush et al. 1997a, Giménez \& Yannicelli 2000) or Central America (Belize; Farnsworth \& Ellison 1996). The larger number of studies conducted in temperate areas was probably unrelated to particularly favourable environmental conditions for field work, since even tropical areas have not been investigated in detail for this specific topic (but see Farnsworth \& Ellison 1996, Hughes et al. 1999). Moreover, most papers focused on rocky intertidal habitats. The distributional patterns of both populations and assemblages of intertidal soft bottoms have been explored to a lesser extent than those of hard bottoms (Lindegarth et al. 1995, Thrush et al. 1997a, Giménez \& Yannicelli 2000). The reason for this bias possibly resides in the long processing time of the large numbers of replicates that are required when a hierarchical sampling design is used. Of a total of 39 studies (Table 1), 18 explicitly recognised that rocky intertidal habitats are very convenient for fieldwork. The remaining papers dealt with the shallow subtidal (not deeper than $50 \mathrm{~m}$ ), but the information was fragmented among shallow rocky bottoms (Kennelly \& Underwood 1992, Fraschetti et al. 2001, Fowler-Walker \& Connell 2002, Irving et al. 2004), bioconstructions (coralligenous formations, coral reefs) (Hughes et al. 1999, Ferdeghini et al. 2000), and soft bottoms (Morrisey et al. 1992, Li et al. 1997, Kendall \& Widdicombe 1999, Stark et al. 2003, Zajac et al. 2003). Lagoons and estuaries, particularly relevant in terms of management of coastal habitats, have been largely neglected (but see Hodda 1990, Edgar \& Barret 2002, Ysebaert \& Herman 2002, De Biasi et al. 2003).

Only a few papers quantified the relative contribution of newly settled, juvenile, or adult organisms to the distributional patterns of the same species, also distinguishing brooders from free-spawners (Åberg \& Pavia 1997, Hyder et al. 1998, Hughes et al. 1999,
Benedetti-Cecchi et al. 2000, Jenkins et al. 2000). There are 3 papers (Fowler-Walker \& Connell 2002, Irving et al. 2004, Kelaher et al. 2004) that have examined spatial patterns over very broad spatial scales (1000s of kilometers), at the expense of detailed middle and/or small-scale analyses. Conversely, studies on intertidal gastropods have provided very detailed analyses of spatial patterns at scales ranging from centimeters to kilometers (the latter already being a 'large scale' for the organisms examined), but did not include regional comparisons (Chapman 1994a,b, 1995, 2002).

Only 1 paper could not identify significant variation at any of the scales investigated (Kendall \& Widdicombe 1999), while other studies found significant variability at all the scales examined (e.g. Underwood \& Chapman 1998b, Menconi et al. 1999, Coleman 2002, present study — see below).

Fowler-Walker \& Connell (2002) and Irving et al. (2004) illustrated substantial variation in cover of benthic algae among sites kilometers apart, whereas variation was negligible at the scale of location (100s of kilometers) and at the regional scale (1000s of kilometers). Similarly, Åberg \& Pavia (1997) showed differences in abundance of juvenile of the brown algae Ascophyllum nodosum at small scales, but not at the regional scale, while different results were obtained for adult individuals. Thus, repeatable patterns occurred over broad, but not over small spatial extents in these studies.

Significant variation in recruitment at all the spatial scales investigated (from 10s of meters to $100 \mathrm{~s}-1000 \mathrm{~s}$ of kilometers) was found by Jenkins et al. (2000) in a study relating settlement and recruitment of the barnacle Semibalanus balanoides. In contrast, a study examining a suite of response variables of the same species (from density to growth) indicated that most of the variability occurred among locations 100 s to 1000s of kilometers apart (Jenkins et al. 2001). Significant differences were also found among sites 10s of meters apart for most variables, while variance components showed that differences between sampling units less than $0.5 \mathrm{~m}$ apart accounted for a low amount of the overall variability (Jenkins et al. 2001). Kelaher et al. (2004) found consistent differences across locations (1000s of kilometers) in the diversity and abundance of molluscs in coralline algal turf at the scale of site (10s of meters), suggesting possible generalities in the dominant processes that create such variation.

Nearly all populations and assemblages showed a patchy distribution at small spatial scales (the only exception being epiphytic macroalgae on Posidonia coriacea; Vanderklift \& Lavery 2000). Apparently, this was the only scale at which a pattern common to most organisms emerged. Patterns became idiosyncratic 


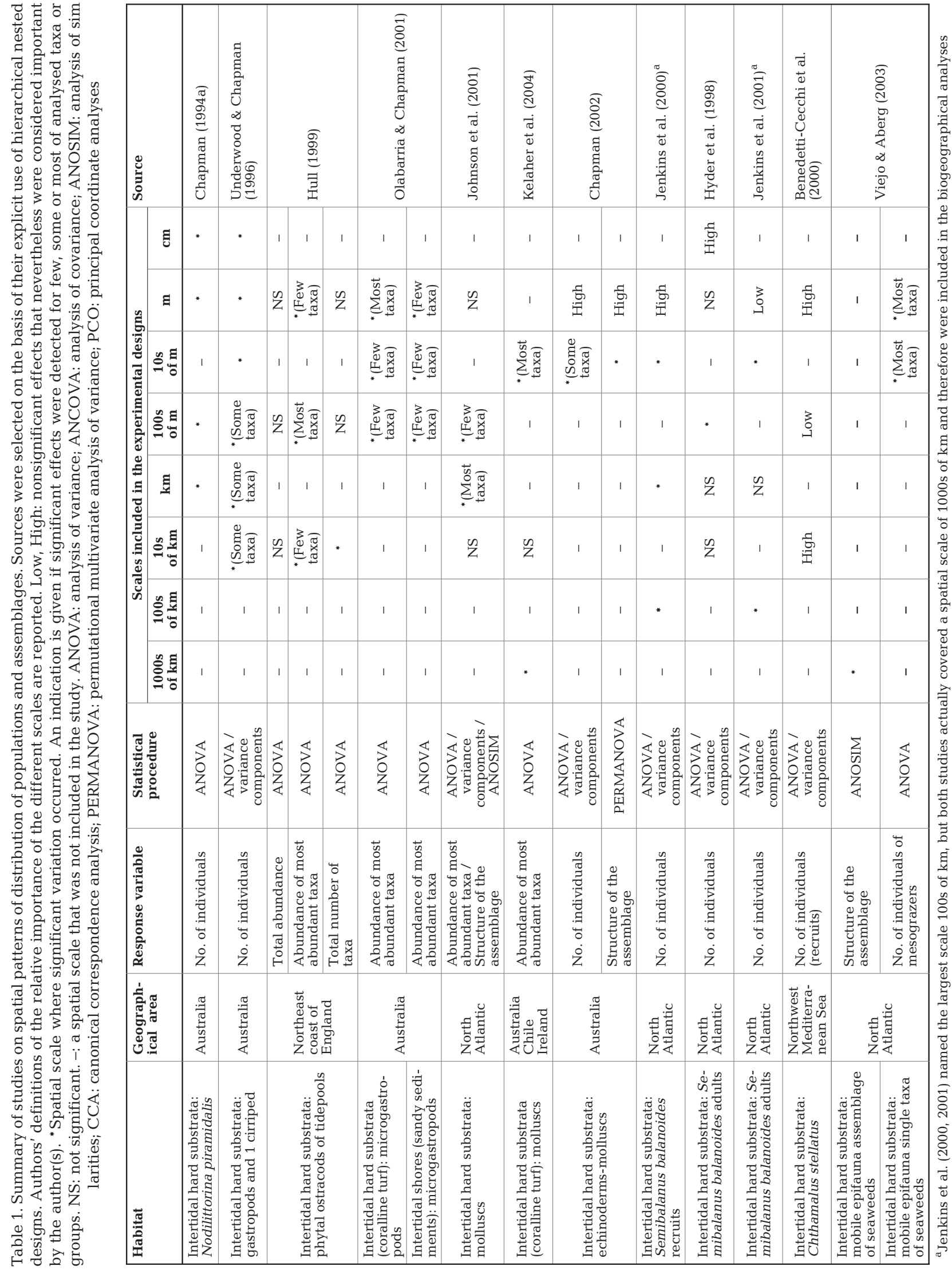




\begin{tabular}{|c|c|c|c|c|c|c|c|c|c|c|c|c|c|c|c|c|c|c|c|c|c|c|}
\hline 总 & 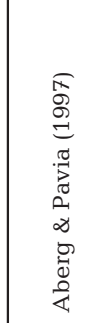 & 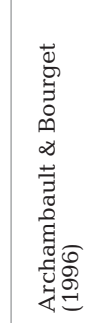 & 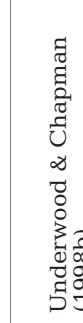 & 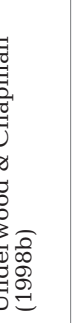 & 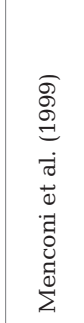 & 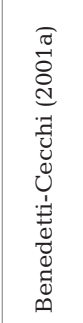 & & 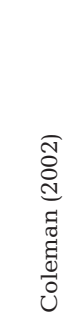 & & & 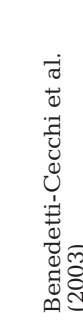 & & & 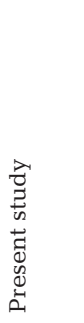 & 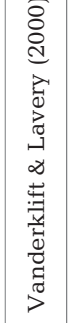 & 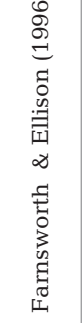 & 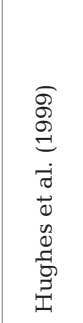 & 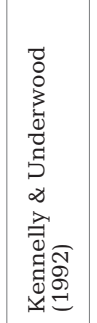 & 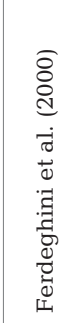 & & 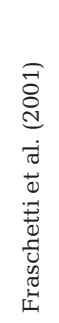 & \\
\hline$\Xi$ & 虽 & 苟. & 1 & 1 & * & 1 & 㿣 & 虽 & 司 & 홀 & 1 & 1 & 1 & 1 & * & * & $\begin{array}{lll} & 1 & 1\end{array}$ & 1 & 1 & 1 & 1 & 1 \\
\hline 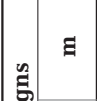 & * & \begin{tabular}{l|l}
1 & 1
\end{tabular} & . & * & 1 & 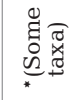 & 1 & 1 & 1 & 1 & 1 & 1 & 㺼 & 绨 & I & $\tilde{Z}$ & \begin{tabular}{l|l}
$\tilde{Z}$ & $\tilde{Z}$ \\
\end{tabular} & * & 1 & 1 & 1 & 点 \\
\hline 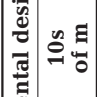 & * & $\begin{array}{lll}1 & 1\end{array}$ & * & . & . & 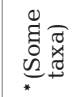 & . & * & * & * & 1 & 1 & 1 & 1 & * & * & $\begin{array}{lll}1 & 1\end{array}$ & * & 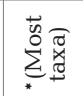 & 1 & 1 & 1 \\
\hline 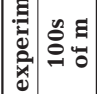 & I & * $\quad \bar{z}$ & 1 & 1 & 1 & $\tilde{Z}$ & 1 & 1 & 1 & 1 & 1 & 1 & 1 & 1 & 1 & * & \begin{tabular}{l|l}
1 & 1
\end{tabular} & 1 & 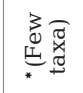 & 1 & I & 1 \\
\hline 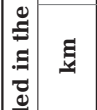 & $\tilde{Z}$ & $\frac{n}{Z}$ &. & * & 1 & 1 & 1 & 1 & 1 & 1 & 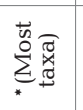 & * & . & * & 氮 & * & * & * & 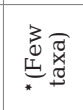 & 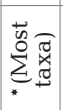 & . & $\cdot$ \\
\hline 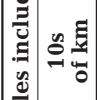 & 1 & \begin{tabular}{l|l}
1 & 1
\end{tabular} & 1 & 1 & . & 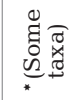 & * & * & * & * & 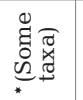 & * & . & . & 1 & 1 & $\begin{array}{ll}n & \Omega \\
Z\end{array}$ & 1 & 1 & 1 & 1 & 1 \\
\hline מूu & 1 & \begin{tabular}{l|l}
1 & 1
\end{tabular} & 1 & 1 & 1 & 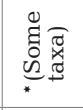 & 1 & 1 & 1 & 1 & 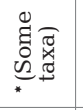 & * & 1 & 1 & 1 & 1 & $\tilde{z} \cdot$ & . & 1 & 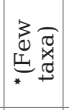 & . & $\cdot$ \\
\hline 突 & $\tilde{Z}$ & \begin{tabular}{l|l}
1 & 1
\end{tabular} & 1 & 1 & I & 1 & 1 & & 1 & 1 & 1 & 1 & Z & * & 1 & 1 & \begin{tabular}{l|l}
1 & 1
\end{tabular} & 1 & 1 & I & 1 & 1 \\
\hline 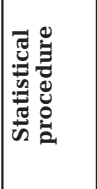 & 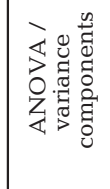 & 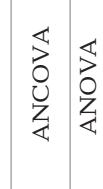 & 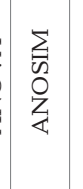 & 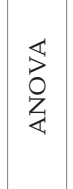 & $\begin{array}{l}\overleftrightarrow{1} \\
0 \\
z\end{array}$ & 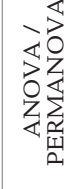 & $\begin{array}{l}\sum \\
n \\
0 \\
Z \\
z \\
Z\end{array}$ & 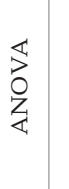 & 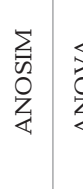 & $\begin{array}{l}\mathbb{4} \\
0 \\
0 \\
4\end{array}$ & 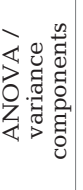 & $\begin{array}{l}\sum \\
\text { Un } \\
0 \\
\sum_{4}\end{array}$ & & 婄 & $\begin{array}{l}\sum \\
n \\
0 \\
0 \\
z \\
z\end{array}$ & 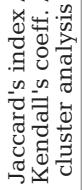 & 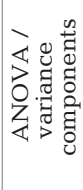 & $\begin{array}{l}\overleftrightarrow{1} \\
0 \\
z \\
\&\end{array}$ & $\begin{array}{l}\overleftrightarrow{4} \\
0 \\
0 \\
z\end{array}$ & $\begin{array}{l}\overleftrightarrow{3} \\
0 \\
z \\
z\end{array}$ & 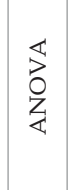 & $\begin{array}{l}\sum_{n} \\
0 \\
0 \\
z \\
z\end{array}$ \\
\hline 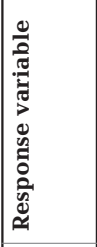 & 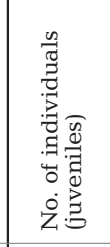 & 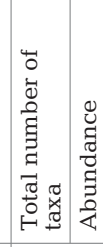 & 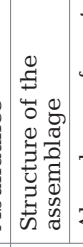 & 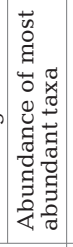 & 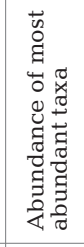 & 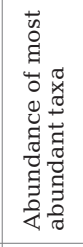 & 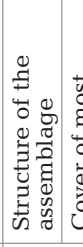 & 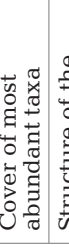 & 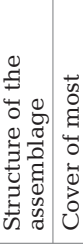 & 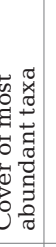 & 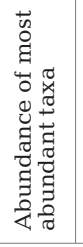 & 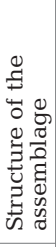 & & 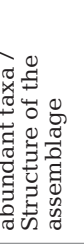 & 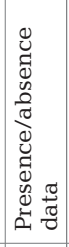 & 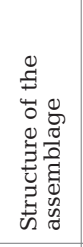 & 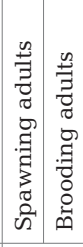 & 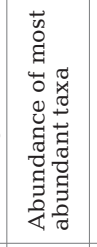 & 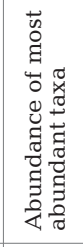 & 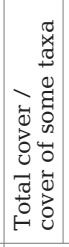 & 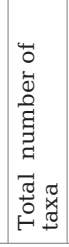 & 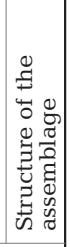 \\
\hline 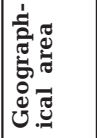 & 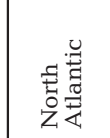 & $\begin{array}{l}\pi \\
\pi \\
\pi \\
0 \\
0\end{array}$ & 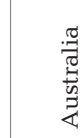 & 营 & 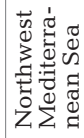 & 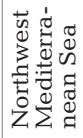 & & 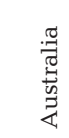 & & & 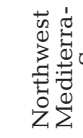 & & & 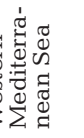 & 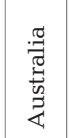 & & 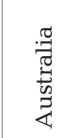 & 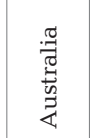 & 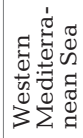 & & & \\
\hline 苞 & 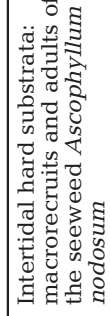 & 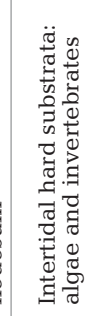 & 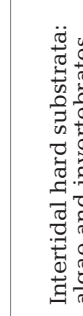 & 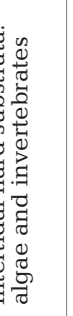 & 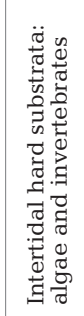 & 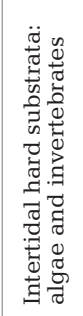 & 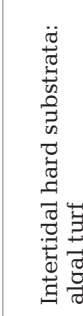 & & 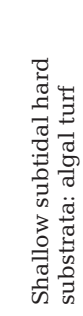 & & 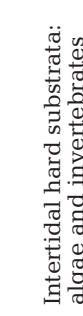 & & 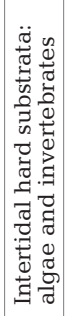 & 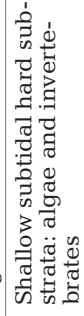 & 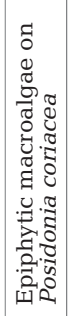 & 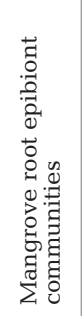 & 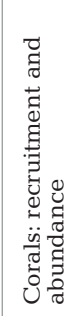 & 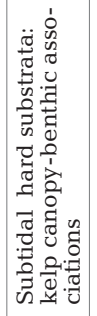 & 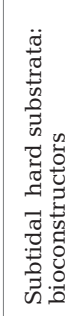 & & 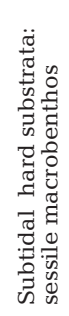 & \\
\hline
\end{tabular}




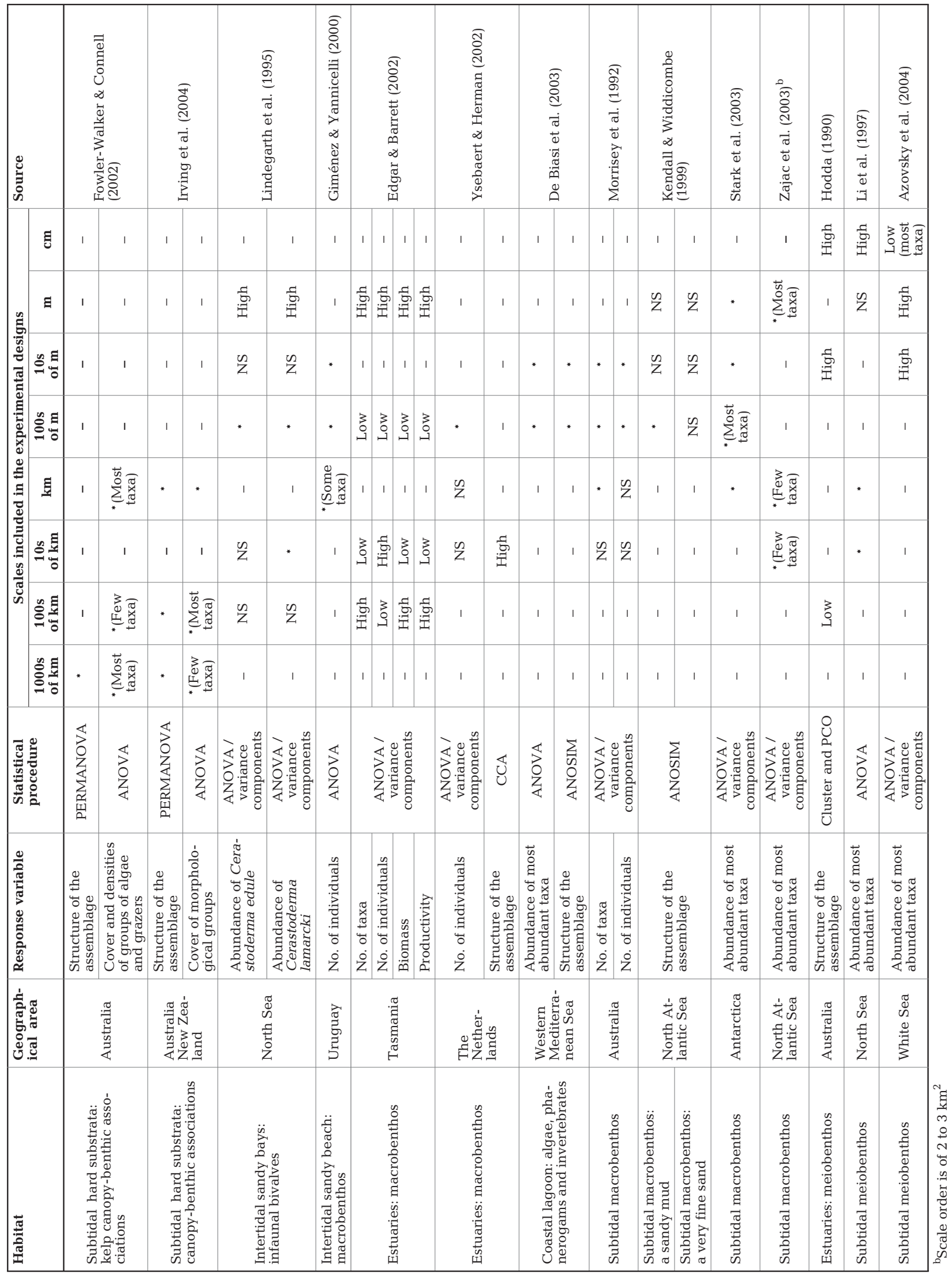


both for modular and individual organisms when moving above the scale of meters (Farnsworth \& Ellison 1996, Hyder et al. 1998, Hughes et al. 1999, Hull 1999, Jenkins et al. 2001, Olabarria \& Chapman 2001).

Finally, very few studies examined simultaneously spatial and temporal variation, so that tests of space $\times$ time interactions are uncommon in the literature (Kennelly \& Underwood 1992, Åberg \& Pavia 1997, Underwood \& Chapman 1998b, Menconi et al. 1999, Jenkins et al. 2000, Chapman 2002, Ysebaert \& Herman 2002, De Biasi et al. 2003).

\section{Present study}

\section{Midshore assemblage}

Overall, 18 taxa were identified. Of these, 5 were identified to species. The most common organisms were cyanobacteria (Rivularia spp.), gastropods (the limpets Patella rustica Linné and P. aspera Röding, the littorinid snail Melaraphe neritoides [Linné]), barnacles (Chthamalus stellatus [Poli]) and encrusting calcified red algae (including Lithophyllum sp. and Peyssonnelia sp.).

Nested analyses: Results of ANOVAs of mean percentage cover and total number of taxa are summarised in Table 2. Both variables showed no significant differences at the scale of region and locations, but differed significantly at the scale of site. The estimate of residual variance was always larger than the variance components associated with larger spatial scales, indicating that variation among replicate units was important.

ANOVA was also performed to compare spatial variation across scales for the most abundant taxa. Table 3 summarises results for bacteria, encrusting calcified red algae (ECR), Chthamalus stellatus and Patella spp. All taxa differed significantly at the scale of site, whereas there were no differences among locations and between regions. Variance components exhibited the same pattern described above for the mean per-

Table 2. ANOVA testing for spatial differences in mean cover and mean number of taxa in the 2 habitats $\left({ }^{* * *} \mathrm{p}<0.001 ;{ }^{*} \mathrm{p}<0.05\right.$; ns: not significant) at scales of region, location and site. Estimates of variance components are included

\begin{tabular}{|c|c|c|c|c|c|c|c|}
\hline \multirow{2}{*}{ Source } & \multirow[b]{2}{*}{ df } & \multicolumn{3}{|c|}{ Cover } & \multicolumn{3}{|c|}{ Number of taxa } \\
\hline & & MS & $F$ & $\begin{array}{l}\text { Variance } \\
\text { component }\end{array}$ & MS & $F$ & $\begin{array}{l}\text { Variance } \\
\text { component }\end{array}$ \\
\hline \multicolumn{8}{|l|}{ Midshore assemblage } \\
\hline Region = R & 1 & 1939.89 & $0.66^{\mathrm{ns}}$ & 0.00 & 19.56 & $5.20^{\mathrm{ns}}$ & 0.54 \\
\hline Location $(\mathrm{R})=\mathrm{L}(\mathrm{R})$ & 12 & 2951.71 & $1.78^{\mathrm{ns}}$ & 60.95 & 3.76 & $0.85^{\text {ns }}$ & 0.00 \\
\hline $\operatorname{Sites}(\mathrm{L}(\mathrm{R}))=\mathrm{S}(\mathrm{L}(\mathrm{R}))$ & 42 & 1654.80 & $7.76^{* * *}$ & 288.30 & 4.45 & $3.56^{* * *}$ & 0.61 \\
\hline Residual & 224 & 213.32 & & 213.32 & 1.25 & & 1.25 \\
\hline Total & 279 & & & & & & \\
\hline Cochran's $C$-test & \multirow{2}{*}{\multicolumn{3}{|c|}{$\begin{array}{l}0.07^{\text {ns }} \\
\text { None }\end{array}$}} & & \multicolumn{3}{|c|}{$0.11^{*}$} \\
\hline Transformation & & & & & & & ne \\
\hline \multicolumn{8}{|l|}{ Lowshore assemblage } \\
\hline Region $=\mathrm{R}$ & 1 & 4690.41 & $2.31^{\mathrm{ns}}$ & 19.01 & 18.51 & $0.31^{\mathrm{ns}}$ & 0.00 \\
\hline Location $(\mathrm{R})=\mathrm{L}(\mathrm{R})$ & 12 & 2029.35 & $3.53^{* * *}$ & 72.71 & 60.36 & $4.48^{* * *}$ & 2.18 \\
\hline $\operatorname{Sites}(\mathrm{L}(\mathrm{R}))=\mathrm{S}(\mathrm{L}(\mathrm{R}))$ & 42 & 575.21 & $2.43^{* * *}$ & 67.64 & 13.49 & $2.82^{* * *}$ & 1.74 \\
\hline Residual & 224 & 237.00 & & 237.00 & 4.78 & & 4.78 \\
\hline Total & 279 & & & & & & \\
\hline Cochran's $C$-test & \multirow{2}{*}{\multicolumn{3}{|c|}{$\begin{array}{l}0.07^{\text {ns }} \\
\text { None }\end{array}$}} & & \multirow{2}{*}{\multicolumn{3}{|c|}{$\begin{array}{l}0.06^{\mathrm{ns}} \\
\text { None }\end{array}$}} \\
\hline Transformation & & & & & & & \\
\hline
\end{tabular}

Table 3. ANOVA testing for spatial differences in mean percentage cover of abundant taxa in midshore habitat. ECR: encrusting calcified red algae. ${ }^{* * *} \mathrm{p}<0.001 ;$ ns: not significant

\begin{tabular}{|c|c|c|c|c|c|c|c|c|c|c|}
\hline \multirow[t]{2}{*}{ Source } & \multicolumn{3}{|c|}{ Region $=\mathrm{R}$} & \multicolumn{3}{|c|}{ Location $(\mathrm{R})=\mathrm{L}(\mathrm{R})$} & \multicolumn{3}{|c|}{ Sites $(\mathrm{L}(\mathrm{R}))=\mathrm{S}(\mathrm{L}(\mathrm{R}))$} & \multirow{2}{*}{ Residual } \\
\hline & MS & $F$ & $\begin{array}{l}\text { Variance } \\
\text { component }\end{array}$ & MS & $F$ & $\begin{array}{l}\text { Variance } \\
\text { component }\end{array}$ & MS & $F$ & $\begin{array}{l}\text { Variance } \\
\text { omponent }\end{array}$ & \\
\hline Bacteria $^{\mathrm{a}}$ & 0.80 & $0.02^{\mathrm{ns}}$ & 0.00 & 44.16 & $1.55^{\mathrm{ns}}$ & 0.79 & 28.41 & $2.00^{* * *}$ & 2.84 & 14.18 \\
\hline Chthamalus stellatus $^{\mathrm{a}}$ & 2206.41 & $2.13^{\mathrm{ns}}$ & 8.36 & 1035.07 & $1.24^{\mathrm{ns}}$ & 9.89 & 837.19 & $13.01^{* * *}$ & 154.56 & 64.35 \\
\hline Patella spp. $^{\mathrm{a}}$ & 304.51 & $1.07^{\mathrm{ns}}$ & 0.13 & 285.60 & $1.80^{\mathrm{ns}}$ & 6.35 & 158.43 & $4.60^{* * *}$ & 24.79 & 34.46 \\
\hline ECR & 2123.00 & $4.78^{\mathrm{ns}}$ & 11.99 & 443.95 & $1.84^{\mathrm{ns}}$ & 6.92 & 305.60 & $2.95^{* * *}$ & 286.85 & 90.73 \\
\hline
\end{tabular}


centage cover and total number of taxa, except for $C$. stellatus, in which most of the variation was observed at the scale of site.

PERMANOVA provided evidence of 2 relevant scales of spatial variation: the scale of location and that of site (Table 4). No significant difference was found at the
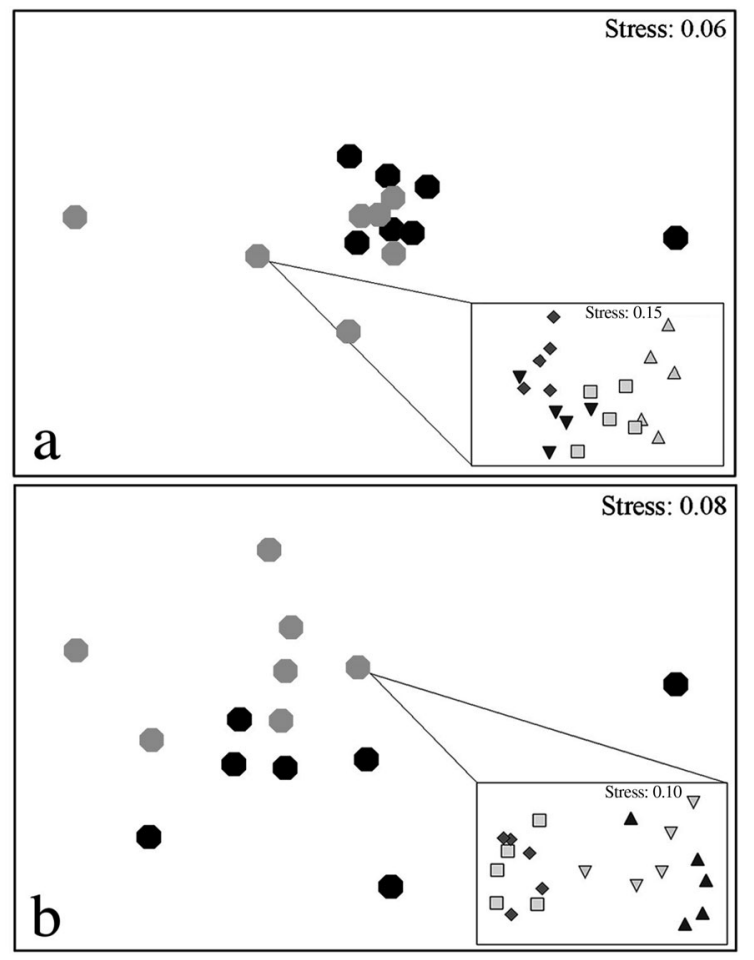

Fig. 2. Non-metric multidimensional scaling ordinations (nMDS plots) on the basis of Bray-Curtis dissimilarity measure of (a) centroids of 14 location cells of midshore habitat and (b) centroids of 14 location cells of lowshore habitat. (๑) 7 locations on the Ionian coast of Greece; () 7 locations on the Apulian coast of Italy. Insets: in each habitat, data from a single location were analysed separately and the individual replicates of the 4 sites of that location are also shown as subplots, in which symbols identify 5 replicate quadrats for each of the 4 sites scale of region. Estimates of multivariate variation increased with decreasing spatial scale. Residual variation, indicating multivariate heterogeneity among quadrats, was much larger than variation at any other scale. There was a clear pattern of decreasing multivariate variation from small to large spatial scales (Table 4). Visual inspection of nMDS plots reflected the results of the PERMANOVA (Fig. 2a): the structure of the assemblage of the midshore habitat showed a negligible separation between the 2 regions. Most locations were intermingled and there was no evidence of regional variation. An illustrative example of patterns of variation at the level of individual sites within one of the seven locations is shown in Fig. 2a.

Pairwise comparisons: The analyses based on pairwise comparisons among sampling units indicated that most of the variation in univariate data was among quadrats, with no further contribution of variability added by larger scales (see results of SNK tests, Fig. 3). The only exception was represented by bacteria (Fig. $3)$, for which the analysis revealed significant differences among scales. Graphical inspection suggested that sites added a significant contribution of variance above that of quadrats, but the SNK test could not provide a clear alternative to the null hypothesis. The analysis of multivariate variation also provided evidence of largest variability at the scale of replicate quadrats (Fig. 4a).

\section{Lowshore assemblage}

The canopy-forming species Cystoseira amentacea Bory var. stricta Montagne was dominant along the surveyed coast, but occasionally C. compressa (Esper) Gerloff \& Nizamuddin and C. barbatula Kützing also occurred in samples. Overall, 54 taxa (16 identified to species) were counted in the assemblage under the canopy. They included Corallina elongata Ellis et Solander, Valonia utricularis (Roth) C. Agardh, and

Table 4. Results of PERMANOVAs testing for spatial differences in structure of assemblages at scales of region, location and site. Analyses based on Bray-Curtis dissimilarities from untransformed data. Each term was tested using 999 random permutations of appropriate units. Estimates of multivariate variation are given for each spatial scale. ${ }^{* *} \mathrm{p}<0.01 ;{ }^{* * *} \mathrm{p}<0.001$; ns: not significant

\begin{tabular}{|c|c|c|c|c|c|c|c|}
\hline \multirow[t]{2}{*}{ Source } & \multirow[b]{2}{*}{ df } & \multicolumn{3}{|c|}{ Midshore assemblage } & \multicolumn{3}{|c|}{ Lowshore assemblage } \\
\hline & & MS & $F$ & $\begin{array}{c}\text { Estimates of } \\
\text { spatial variation }\end{array}$ & MS & $F$ & $\begin{array}{c}\text { Estimates of } \\
\text { spatial variation }\end{array}$ \\
\hline Region $=\mathrm{R}$ & 1 & 15370.84 & $1.48^{\mathrm{ns}}$ & 35.61 & 59925.99 & $2.76^{* *}$ & 273.09 \\
\hline Location $(\mathrm{R})=\mathrm{L}(\mathrm{R})$ & 12 & 10385.41 & $2.02^{* * *}$ & 261.88 & 21693.53 & $4.32^{* * *}$ & 833.59 \\
\hline $\operatorname{Sites}(\mathrm{L}(\mathrm{R}))=\mathrm{S}(\mathrm{L}(\mathrm{R}))$ & 42 & 5147.74 & $3.53^{* * *}$ & 738.15 & 5021.73 & $2.91^{* * *}$ & 659.53 \\
\hline Residual & 224 & 1456.97 & & 1456.97 & 1724.10 & & 1724.10 \\
\hline Total & 279 & & & & & & \\
\hline Transformation & None & & & & & None & \\
\hline
\end{tabular}


Fig. 3. Mean (+1 SE), $\mathrm{n}=24)$ estimates of variance in abundance (log form) of algae and invertebrates at 4 spatial scales in the midshore habitat. Results of SNK tests comparing variances at different scales are included. Q: quadrat; QS: quadrat + site; QSL: quadrat + site + location; QSLR: quadrat + site + location + region. $(*)$ The only interpretable result, as Q was not consistently ranked by SNK test
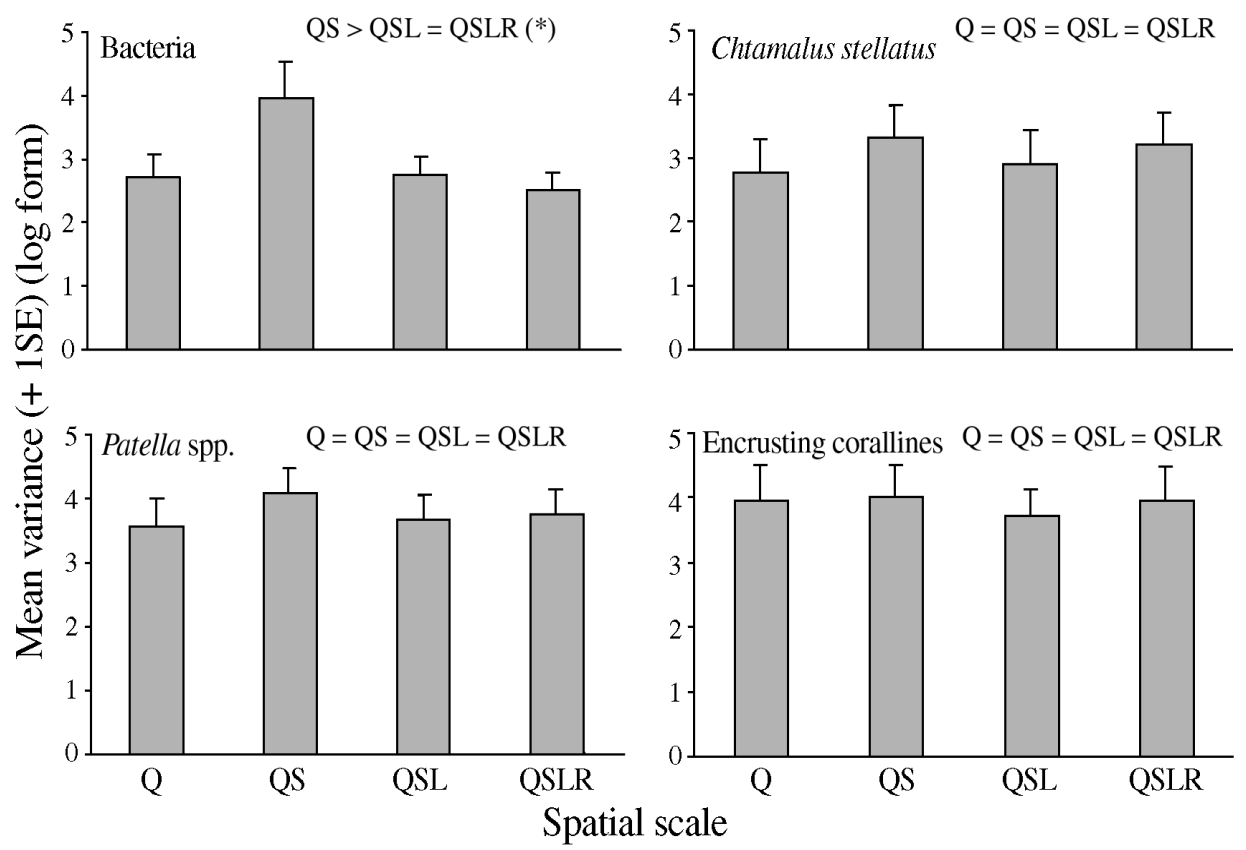

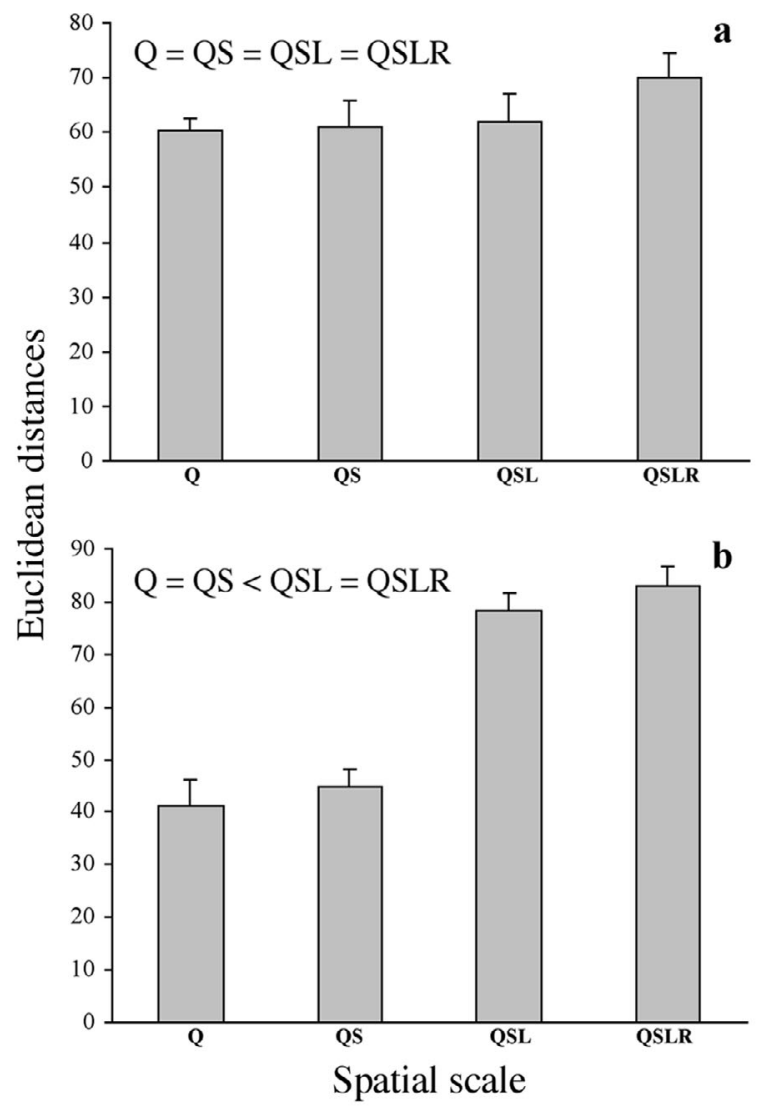

Fig. 4. Mean $(+\mathrm{SE}, \mathrm{n}=24)$ estimates of multivariate variation at 4 spatial scales. Data expressed as Euclidean distance between any pair of observations using principal coordinates. (a) midshore habitat; (b) lowshore habitat. Results of SNK tests comparing Euclidean distances at different scales are included; abbreviations as in Fig. 3
Halimeda tuna (Ellis et Solander) Lamouroux among the algae, and the sponge Ircinia foetida (Schmidt) and the ascidian Diplosoma listerianum (Milne-Edwards) among the invertebrates.

Nested analyses: Results of ANOVAs on mean percentage cover and number of taxa are summarised in Table 2. Both variables showed no significant differences at the scale of region, but differed significantly at the scale of location and site. Most variability occurred at the smallest spatial scale, among quadrats, as indicated by the large values of the residual mean squares.

Analysis of variance (Table 5) indicated that all the variables analysed did not differ at the scale of region. In particular, Cystoseira amentacea, Corallina elongata, the ascidian Diplosoma listerianum, articulated corallines and dark filamentous algae were characterised by significant differences in their cover at the scales of location and site. In contrast, ECR varied significantly only at the scale of location. Variance components at the scale of replicate quadrats, as indicated by residual mean squares, were always larger than those at the other scales irrespective of the taxon considered.

PERMANOVA provided evidence that the structure of understorey assemblages differed significantly at all scales considered in the study (Table 4). Estimates of multivariate variation increased with decreasing spatial scale, the largest variation occurring among replicate quadrats, as indicated by the residual mean square.

The nMDS plot (Fig. 2b) illustrates clearer differences between the 2 regions than those observed for the midshore assemblage (Fig. 2a). In addition, locations were widely scattered, providing evidence of 
Table 5. ANOVA testing for spatial differences in mean percentage cover of abundant taxa in lowshore habitat. ${ }^{* *} \mathrm{p}<0.01$; ${ }^{* * *} \mathrm{p}<0.001$; ns: not significant. Variances were heterogeneous in all cases. Abbreviations as in Table 3

\begin{tabular}{|c|c|c|c|c|c|c|c|c|c|c|}
\hline \multirow[t]{2}{*}{ Source } & \multicolumn{3}{|c|}{ Region $=\mathrm{R}$} & \multicolumn{3}{|c|}{ Location $(\mathrm{R})=\mathrm{L}(\mathrm{R})$} & \multicolumn{3}{|c|}{$\operatorname{Sites}(L[R])=S(L[R])$} & \multirow[t]{2}{*}{ Residual } \\
\hline & MS & $F$ & $\begin{array}{l}\text { Variance } \\
\text { component }\end{array}$ & MS & $F$ & $\begin{array}{l}\text { Variance } \\
\text { component }\end{array}$ & MS & $F$ & $\begin{array}{l}\text { Variance } \\
\text { component }\end{array}$ & \\
\hline Cystoseira spp. & 939.88 & $0.12^{\text {ns }}$ & 0.00 & 7355.04 & $5.84^{* * *}$ & 304.80 & 1259.02 & $3.41^{* * *}$ & 178.03 & 368.89 \\
\hline Hydroids & 391.29 & $4.11^{\mathrm{ns}}$ & 2.11 & 95.15 & $1.61^{\mathrm{ns}}$ & 1.80 & 58.99 & $1.82^{* *}$ & 5.31 & 32.43 \\
\hline Sea anemones & 23.43 & $1.69^{\mathrm{a}}$ & 0.07 & 13.89 & $1.46^{\mathrm{ns}}$ & 0.21 & 9.51 & $3.66^{* * *}$ & 1.38 & 2.60 \\
\hline Didemnidae & 1160.36 & $7.18^{\mathrm{a}}$ & 7.13 & 161.57 & $2.56^{\mathrm{a}}$ & 4.92 & 63.19 & $3.14^{* * *}$ & 8.62 & 20.10 \\
\hline Diplosoma listerianum & 117.00 & $6.03^{\mathrm{a}}$ & 0.70 & 19.39 & $3.06^{* * *}$ & 0.65 & 6.34 & $2.31^{* * *}$ & 0.73 & 2.74 \\
\hline Articulated corallines & 284.01 & $0.51^{\mathrm{ns}}$ & 0.00 & 536.93 & $2.30^{* *}$ & 15.16 & 233.73 & $3.87^{* * *}$ & 34.66 & 60.41 \\
\hline Corallina elongata & 5688.01 & $6.72^{\mathrm{a}}$ & 34.58 & 846.18 & $3.26^{* *}$ & 29.32 & 259.80 & $3.67^{* * *}$ & 37.79 & 70.87 \\
\hline Dark filamentous algae & 78.23 & $0.59^{\text {ns }}$ & 0.00 & 127.60 & $3.08^{* *}$ & 4.31 & 41.45 & $3.42^{* * *}$ & 5.86 & 12.13 \\
\hline ECR & 393.65 & $2.75^{\text {ns }}$ & 1.79 & 142.92 & $2.84^{* *}$ & 4.63 & 50.28 & $1.56^{\mathrm{a}}$ & 3.62 & 32.19 \\
\hline
\end{tabular}

important variation at the scale of kilometers. As for the midshore habitat, the nMDS in Fig. $2 \mathrm{~b}$ shows in more detail an example of the spatial variability of the assemblage within one location, at the scale of site. Also in this case, patchiness at the scale of replicate quadrats was very large (Fig. 2b: inset).

Pairwise comparisons: The analysis of spatial variation based on pairwise comparisons highlighted the importance of small-scale variability, indicating more variation at the scale of quadrats compared to that occurring at any other scale in all taxa (SNK test, Fig. 5). The analysis of multivariate variation showed that locations added a significant contribution of variance above that of replicate quadrats (Fig. 4b).

\section{DISCUSSION}

Resolving the relative contribution of local versus regional processes may be key to understanding global patterns of species diversity (Huston 1999). Over very small spatial scales (centimeters to meters), experimental manipulations and descriptive studies have provided considerable insights into local ecological dynamics (Connolly \& Roughgarden 1998). At larger scales (100s to 1000 s of kilometers), traditional biogeographic studies provided perspectives on the processes influencing whole assemblages (Brown 1995, Maurer 1999, Broitman et al. 2001). Between local and biogeographic scales, however, there is a suite of processes that only recently has received proper attention, and information has yet to be integrated.

Our review of the literature highlighted a general theme: variability is large at small scales in almost all the habitats examined. Small-scale patchiness in the distribution of benthic organisms is repeatedly demonstrated, since nearly all populations and assemblages (even in soft sediments, usually considered as homogeneous habitats) show a patchy distribution for all the consid- ered variables at the scale of centimeters. With very few exceptions (Farnsworth \& Ellison 1996, Li et al. 1997, Hyder et al. 1998), small-scale patchiness is still common when scales increase from centimeters to meters. The significance of this large spatial variance at the small scale has been discussed in several papers and suggests that local biological interactions and small-scale physical processes are pervasive in marine systems (see Underwood \& Petraitis 1993, Underwood 1996, Legendre et al. 1997, Benedetti-Cecchi et al. 2001a, Coleman 2002, for detailed discussions of the potential processes that may generate large spatial variance at a small scale), similar to the situation in terrestrial habitats (Picket \& White 1985, Leponce et al. 2004).

Not all studies, however, concur that spatial variation decreases as the scale of measurement increases. Denny et al. (2004), for example, found that the variance of several physical and biological variables measured along a stretch of rocky coast in California increased with increasing spatial scale. Denny et al. (2004) suggested that the topography of the substratum may affect scaling relationships in intertidal habitats. In contrast to the studies included in our review of the literature, Denny et al. (2004) examined patterns of variability along continuous spatial scales and used spectral analyses to characterise these patterns. Thus, it is possible that differences in sampling design (continuous versus discrete spatial scales) and method of analysis (spectral analyses versus analysis of variance) are responsible for the discrepancy between the results reported by Denny et al. (2004) and those of the studies reviewed by us.

Methodological issues, however, may not be the only cause of this discrepancy. Johnson et al. (2001), using a hierarchical sampling design to investigate spatial variation in density of intertidal molluscs on rocky shores of the Isle of Man, showed that life history may affect the importance of scale. Species with a larval dispersal stage displayed more variation among shores 

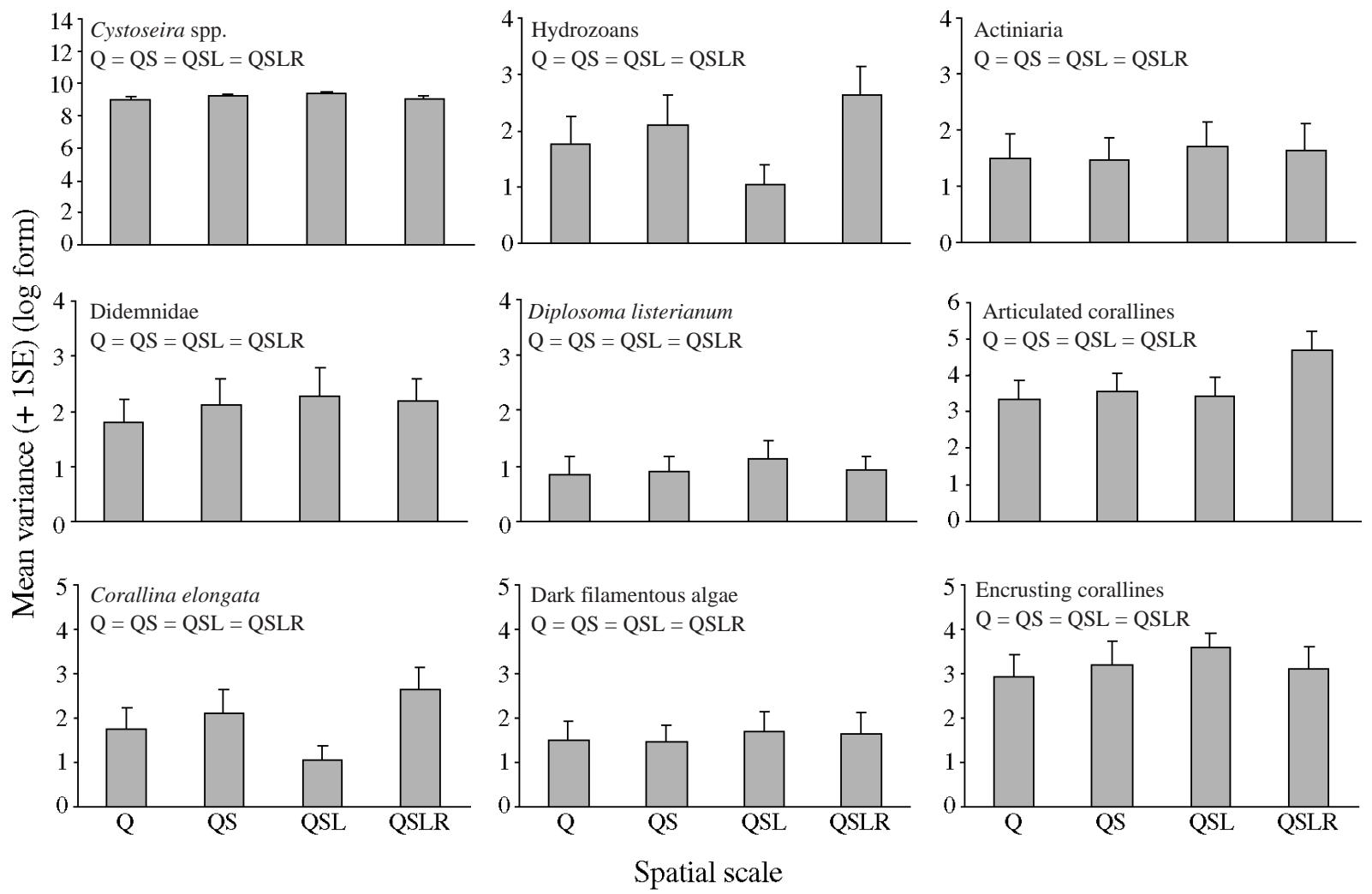

Fig. 5. Mean $(+\mathrm{SE}, \mathrm{n}=24)$ estimates of variance in abundance (log form) of algae and invertebrates at 4 spatial scales in lowshore habitat. Results of SNK tests comparing variances at different scales are included; abbreviations as in Fig. 3

several kilometers apart, whilst species with direct development were more variable among sites 100 s of meters apart. The extent to which the life-history attributes of species and methodological issues affect our perception of the importance of scale is worthy of further scrutinity.

We posed 2 questions at the beginning of this study: (1) To what extent does small-scale variability contribute to large-scale patterns of variation? (2) Is there a pattern of variability that can be generalised across species and habitats? We now explore the extent to which the results of our field study clarify to these issues.

The null hypothesis that spatial patterns were invariant to scale was rejected in our study both for the midshore and the lowshore habitats, although patterns differed between heights on the shore and also depended on the taxa examined. In the midshore habitat, PERMANOVA revealed differences in the structure of assemblages from location to location and from site to site, but no difference at the regional scale. The same result was achieved by ANOVAs for most of the response variables analysed, where no term above the level of site was significant. This suggested that similar processes operated at midshore heights over broad geographical scales. While local patterns were complex, the structure of the assemblage and the distribution of single taxa could be related across space from local to regional scales, suggesting that, at least in this habitat, the findings of small-scale studies may be scaled up to larger areas in agreement with the findings of other studies (Thrush et al. 1997a, Irving et al. 2004). Physical stress in the harsh midshore environment could possibly limit the large-scale variability observed in other habitats (Jackson 1977, Archambault \& Bourget 1996).

The lowshore habitat was heterogeneous at all scales considered. This result indicated that patterns could not be generalised in space for this habitat (Jackson 1977, Crowe \& Underwood 1999) and suggested caution in using the results of small-scale experiments to explain patterns over broad spatial extents (Foster 1990, Brown 1995, Connolly \& Roughgarden 1998).

The general result from the analysis of variance components was in agreement with the results from the survey of the literature, where most variation in patterns of abundance was at the smallest spatial scale. This pattern was observed, with no exception, for all variables examined in each habitat. Of course, these findings are contingent on the specific time at which 
the study was conducted. Temporal replication is needed before drawing any general conclusion, since spatial patterns do not necessarily remain constant over time (Underwood \& Petraitis 1993).

Other authors have addressed the issue of whether local variability can scale up to generate large-scale patterns. Thrush et al. (1997a) and Wootton (2001) provided some evidence that patterns of complexity can be related across space from local to regional scales (1000s of kilometers). Furthermore, Fowler-Walker \& Connell (2002) showed consistent biodiversity patterns over biogeographic scales despite enormous spatial variability at smaller spatial scales. Hughes et al. (2002), in order to derive large-scale biodiversity patterns in space or time from small-scale descriptive data, linked experimental data to a meta-analysis of a vast array of information on coral reef distribution, suggesting that this procedure might be of general relevance. Connolly \& Roughgarden (1998) demonstrated that attempts to synthesise regional differences in the structure of assemblages could largely benefit from considering both the benthic adult and pelagic larval environments. Although important, we believe these examples are still preliminary and, along with the results of our analysis, they show that scaling-up effects are likely to be context-dependent. Consequently, we believe it is still premature to derive general conclusions on scaling-up effects in marine assemblages.

Our data did not reveal consistent patterns of spatial variation at intermediate scales (from 10s of meters to 10 s of kilometers). This situation is also common in the literature, although in a few cases small-scale variability declines progressively (rather than abruptly) with increasing spatial scales of sampling (e.g. Underwood \& Chapman 1996, Olabarria \& Chapman 2001). Indeed, patterns of variation in published studies range from cases in which variability occurs at all scales (e.g. Menconi et al. 1999, Coleman 2002), to cases in which variation is concentrated mostly at a particular scale, as already discussed (e.g. Archambault \& Bourget 1996, Hyder et al. 1998, Hughes et al. 1999, Kendall \& Widdicombe 1999). These results confirm the absence of any single appropriate scale at which populations and assemblages should be investigated, forcing ecologists to adopt a multi-scale approach in analyses of spatial and temporal patterns (Levin 1992, Hewitt et al. 1998).

Documenting the spatial scales at which significant differences in abundances of organisms are found allows the formulation of hypotheses about the relevant processes, which may determine these patterns (Underwood \& Chapman 1996). However, such documentation requires proper evaluation of the efficiency of different methods. In our case, the use of 2 proce- dures was justified by the need to measure variability with the same precision at different scales. Both methods revealed considerable more variability at the scale of replicate quadrats than at the other scales. A difference, however, existed between the methods in the outcome of univariate analyses of lowshore assemblages. Hierarchical ANOVAs revealed significant spatial variation at all scales in lowshore assemblages, whereas pairwise comparisons failed to detect differences above the scale of replicate quadrat. Both methods detected significant variation at small and large spatial scales for multivariate data. To some extent, these results justify the use of a nested analysis of variance to detect patterns at the top of the hierarchy when the immediate lower level is properly replicated. By sampling 7 locations in each region we guaranteed enough power to detect large-scale effects that were not so easily detected in the pairwise comparisons.

Identifying relevant scales of variability, along with the development of innovative statistical techniques (Underwood \& Chapman 1998a, Legendre et al. 2002), is crucial for implementing monitoring programs and environmental impact studies (Thrush et al. 1994, Schoch \& Dethier 1996, Bishop et al. 2002). Small-scale variability has several implications for understanding patterns and processes and in the analysis of environmental impacts. Patchiness may reduce the power of statistical tests, thus calling for careful optimization of experimental design of environmental sampling programs (Benedetti-Cecchi 2001b, Underwood \& Chapman 2003). Changes in small-scale variability have been repeatedly proposed as a diagnostic feature of disturbed marine assemblages (Caswell \& Cohen 1991, Warwick \& Clarke 1993). However, since large variability characterises also non-impacted assemblages, adequate reference conditions should always be used when interpreting variability in disturbed environments.

In conclusion, there is still a need to investigate the spatial pattern of ecological variables in a wider range of habitats and on a larger number of species in marine coastal areas. To date, the only scale that we possibly define as 'critical' or 'characteristic' is that between replicate units, and this small-scale variability is possibly one of the few common patterns between terrestrial and marine habitats. Notwithstanding frequent literature reports, small-scale variability is not 'noise' determined by nonspecific 'stochastic' processes. Rather, patchiness underlies a complex suite of factors that possibly change from place to place and time to time (Coleman et al. 2004). Recognizing the pervasive nature of small-scale spatial variation will be important in understanding causal linkages between patterns and processes and in developing better experimental and sampling designs to unravel these relationships in 
future studies. We suggest that this pattern is common to a wide range of natural systems where assemblages are influenced by complex sets of physical and biological processes such as those operating in the marine environment.

Acknowledgements. Research was funded by the Regione Puglia (INTERREG Greece-Italy project), MURST (COFIN and FIRB projects). The authors acknowledge the support by the MARBEF Network of Excellence 'Marine Biodiversity and Ecosystem Functioning', which is funded in the Community's Sixth Framework Programme (contract no. GOCE-CT-2003505446). C. Vaglio and L. Matinato provided invaluable assistance during fieldwork. G. Guarnieri drafted Fig. 1. S, Bevilacqua helped set up Table 1.

\section{LITERATURE CITED}

Åberg P, Pavia H (1997) Temporal and multiple scale spatial variation in juvenile and adult abundance of the brown alga Ascophyllum nodosum. Mar Ecol Prog Ser 158: 111-119

Anderson MJ (2001a) A new method for non-parametric multivariate analysis of variance. Aust Ecol 26:32-46

Anderson MJ (2001b) Permutation tests for univariate or multivariate analysis of variance and regression. Can J Fish Aquat Sci 58:626-639

Anderson MJ (2005) PERMANOVA: a FORTRAN computer program for permutational multivariate analysis of variance. Department of Statistics, University of Auckland

Anderson MJ, ter Braak CJF (2003) Permutation tests for multi-factorial analysis of variance. J Stat Comput Simul 73:85-113

Archambault P, Bourget E (1996) Scales of coastal heterogeneity and benthic intertidal species richness, diversity and abundance. Mar Ecol Prog Ser 136:111-121

Azovsky AI, Chertoprood ES, Saburova MA, Polikarpov IG (2004) Spatio-temporal variability of micro- and meiobenthic communities in a White Sea intertidal sandflat. Estuar Coast Shelf Sci 60:663-671

Benedetti-Cecchi L (2001a) Variability in abundance of algae and invertebrates at different spatial scales on rocky sea shores. Mar Ecol Prog Ser 215:79-92

Benedetti-Cecchi L (2001b) Beyond BACI: optimization of environmental sampling design through monitoring and simulation. Ecol Appl 11:783-799

Benedetti-Cecchi L, Acunto S, Bulleri F, Cinelli F (2000) Population ecology of the barnacle Chthamalus stellatus in the northwest Mediterranean. Mar Ecol Prog Ser 198:157-170

Benedetti-Cecchi L, Maggi E, Bertocci I, Vaselli S, Micheli F, Osio GC, Cinelli F (2003) Variation in rocky shore assemblages in the northwestern Mediterranean: contrasts between islands and the mainland. J Exp Mar Biol Ecol 293:193-215

Bishop M, Underwood AJ, Archambault P (2002) Sewage and environmental impacts on rocky shores: necessity of identifying relevant spatial scales. Mar Ecol Prog Ser 236: 121-128

Bray JR, Curtis JT (1957) An ordination of the upland forest communities of southern Wisconsin. Ecol Monogr 27: 325-349

Broitman BR, Navarrete SA, Smith F, Gaines SD (2001) Geographic variation of southeastern Pacific intertidal communities. Mar Ecol Prog Ser 224:21-34
Brown JH (1995) Macroecology. University of Chicago Press, Chicago, IL

Caswell H, Cohen JE (1991) Communities in patchy environments: a model of disturbance, competition, and heterogenity. In: Kolasa J, Pickett STA (eds) Ecological heterogenity. Springer-Verlag, New York, p 97-122

Chapman MG (1994a) Small-scale patterns of distribution and size-structure of the intertidal littorinid, Nodilittorina pyramidalis in New South Wales. Aust J Ecol 19:83-95

Chapman MG (1994b) Small-scale patterns of distribution and size-structure of the intertidal littorinid Littorina unifasciata (Gastropoda: Littorinidae) in New South Wales. Aust J Mar Freshw Res: 635-652

Chapman MG (1995) Spatial patterns of shell shape of three species of co-existing littorinid snails in New South Wales, Australia. J Molluscan Stud 61:141-162

Chapman MG (2002) Patterns of spatial and temporal variation of macrofauna under boulders in a sheltered boulder field. Aust Ecol 27:211-228

Chapman MG, Underwood AJ, Skilleter GA (1995) Variability at different spatial scales between a subtidal assemblage exposed to the discharge of sewage and two control assemblages. J Exp Mar Biol Ecol 189:103-122

Coleman RA, Browne M, Theobalds T (2002) Small-scale spatial variability in intertidal and subtidal turfing algal assemblages and the temporal generality of these patterns. J Exp Mar Biol Ecol 267:53-74

Coleman MA, Browne M, Theobalds T (2004) Aggregation as a defense: limpet tenacity changes in response to simulated predator attack. Ecology 85:1153-1159

Connolly RM, Roughgarden J (1998) A latitudinal gradient in Northeast Pacific intertidal community structure: evidence for an oceanographically based synthesis of marine community theory. Am Nat 151:311-326

Crowe TP, Underwood AJ (1999) Differences in dispersal of an intertidal gastropod in two habitats: the need for and design of repeated experimental transplantation. J Exp Mar Biol Ecol 237:31-60

De Biasi AM, Benedetti-Cecchi L, Pacciardi L, Maggi E, Vaselli S, Bertocci I (2003) Spatial heterogeneity in the distribution of plants and benthic invertebrates in the lagoon of Orbetello (Italy). Oceanol Acta 26:39-46

Denny MW, Helmuth B, Leonard GH, Harley CDG, Hunt LJH, Nelson EK (2004) Quantifying scale in ecology: lessons from a wave-swept shore. Ecol Monogr 73:513-532

Dethier MN, Graham ES, Cohen S, Tear LM (1993) Visual versus random-point percent cover estimations: 'objective' is not always better. Mar Ecol Prog Ser 96:93-100

Dungan JL, Perry JN, Dale MRT, Citron-Pousty S, Fortin MJ, Jakomulska A, Miriti M, Rosenberg MS (2002) A balanced view of scale in spatial statistical analysis. Ecography 5: $626-640$

Edgar GJ, Barret NS (2002) Benthic macrofauna in Tasmanian estuaries: scales of distribution and relationships with environmental variables. J Exp Mar Biol Ecol 270:1-24

Farnsworth EJ, Ellison AM (1996) Scale-dependent spatial and temporal variability in biogeography of mangrove root epibiont communities. Ecol Monogr 66:45-66

Ferdeghini F, Acunto S, Cocito S, Cinelli F (2000) Variability at different spatial scales of a coralligenous assemblage at Giannutri Island (Tuscan Archipelago, northwest Mediterranean). Hydrobiologia 440:27-36

Fletcher DJ, Underwood AJ (2002) How to cope with negative estimates of components of variance in ecological field studies. J Exp Mar Biol Ecol 273:89-95

Foster MS (1990) Organization of macroalgal assemblages in the North Pacific: the assumption of homogeneity and the 
illusion of generality. Hydrobiologia 192:21-33

Fowler-Walker MJ, Connell SD (2002) Opposing states of subtidal habitat across temperate Australia: consistency and predictability in kelp canopy-benthic associations. Mar Ecol Prog Ser 240:49-56

Fraschetti S, Bianchi CN, Terlizzi A, Fanelli G, Morri C, Boero F (2001) Spatial variability and human disturbance in shallow subtidal hard substrate assemblages: a regional approach. Mar Ecol Prog Ser 212:1-12

Fraschetti S, Giangrande A, Terlizzi A, Della Tommasa L, Miglietta MP, Boero F (2002) Spatio-temporal variation of hydroids and polychaetes associated with Cystoseira amentacea (Fucales, Phaeophyceae): a regional scale approach. Mar Biol 140:949-957

Giménez L, Yannicelli B (2000) Longshore patterns of distribution of macroinfauna on a Uruguayan sandy beach: an analysis at different spatial scales and of their potential causes. Mar Ecol Prog Ser 199:111-125

Hewitt JE, Thrush SF, Cummings VJ, Turner SJ (1998) The effect of changing sampling scales on our ability to detect effects of large-scale processes on communities. J Exp Mar Biol Ecol 227:251-264

Hodda M (1990) Variation in estuarine littoral nematode populations over three spatial scales. Estuar Coast Shelf Sci 30:325-340

Holling CS (1992) Cross-scale morphology, geometry, and dynamics of ecosystems. Ecol Monogr 62:447-502

Horne JK, Schneider DC (1995) Spatial variance in ecology. Oikos 74:18-26

Hughes TP, Baird AH, Dinsdale EA, Moltschaniwskyj NA, Pratchett MS, Tanner JE, Willis BL (1999) Patterns of recruitment and abundance of corals along the Great Barrier Reef. Nature 397:59-63

Hughes TP, Baird AH, Dinsdale EA, Harriott VJ, Moltschaniwskyj NA, Pratchett MS, Tanner JE, Willis BL (2002) Detecting regional variation using meta-analysis and large-scale sampling: latitudinal patterns in recruitment. Ecology 83:436-451

Hull SH (1999) Comparison of the tidepool phytal ostracod abundance and assemblage structure on three spatial scales. Mar Ecol Prog Ser 182:201-208

Huston MA (1999) Local processes and regional patterns: appropriate scales for understanding variation in the diversity of plants and animals. Oikos 86:393-401

Hyder K, Johnson MP, Hawkins SJ, Gurney WSC (1998) Barnacle demography: evidence for an existing model and spatial scales of variation. Mar Ecol Prog Ser 174:89-99

Irving AD, Connell SD, Gillanders BM (2004) Local complexity in patterns of canopy-benthos associations produces regional patterns across temperate Australasia. Mar Biol 144:361-368

Jackson JBC (1977) Competition on marine hard substrata. The adaptative significance of solitary and colonial stategies. Am Nat 111:743-767

Jenkins SR, Åberg P, Cervin G, Coleman RA and 9 others (2000) Spatial and temporal variation in settlement and recruitment of the intertidal barnacle Semibalanus balanoides (L.) (Crustacea: Cirripedia) over a European scale. J Exp Mar Biol Ecol 243:209-225

Jenkins SR, Åberg P, Cervin G, Coleman RA and 8 others (2001) Population dynamics of the intertidal barnacle Semibalanus balanoides at three European locations: spatial scales of variability. Mar Ecol Prog Ser 217:207-217

Johnson MP, Allcock AL, Pye SE, Chambers SJ, Fitton DM (2001) The effects of dispersal mode on the spatial distribution patterns of intertidal molluscs. J Anim Ecol 70: 641-649
Kelaher BP, Chapman MG, Underwood AJ (2001) Spatial patterns of diverse macrofaunal assemblages in coralline turf and their associations with environmental variables. J Mar Biol Assoc UK 81:917-930

Kelaher BP, Castilla JC, Seed R (2004) Intercontinental test of generality for spatial patterns among diverse molluscan assemblages in coralline algal turf. Mar Ecol Prog Ser 271: 221-231

Kendall MA, Widdicombe S (1999) Small scale patterns in the structure of macrofaunal assemblages of shallow soft sediments. J Exp Mar Biol Ecol 237:127-140

Kennelly SJ, Underwood AJ (1992) Fluctuations in the distribution and abundances of species in sublittoral kelp forests in New South Wales. Aust J Ecol 17:367-382

Kruskal JB, Wish M (1978) Multidimensional scaling. Sage Publications, Beverly Hills, CA

Lawton JH (1996) Patterns in ecology. Oikos 75:145-147

Legendre P, Anderson MJ (1999) Distance-based redundancy analysis: testing multispecies responses in multifactorial ecological experiments. Ecol Monogr 69:1-24

Legendre P, Thrush SF, Cummings VJ, Dayton PK and 9 others (1997) Spatial structure of bivalves in a sandflat: scale and generating processes. J Exp Mar Biol Ecol 216:99-128

Legendre P, Dale MRT, Fortin MJ, Gurevitch J, Hohn M, Myers D (2002) The consequence of spatial structure for the design and analysis of ecological field surveys. Ecography 25:601-615

Leponce M, Theunis L, Delabie JHC, Roisin Y (2004) Scale dependence of diversity measures in a leaf-litter ant assemblage. Ecography 27:253-267

Levin SA (1992) The problem of pattern and scale in ecology. Ecology 73:1943-1967

Li J, Vincx M, Herman PMJ, Heip C (1997) Monitoring meiobenthos using cm-, m- and km-scales in the Southern Bight of the North Sea. Mar Environ Res 43:265-278

Lindegarth M, André C, Jonsson PR (1995) Analysis of the spatial variability in abundance and age structure of two infaunal bivalves, Cerastoderma edule and C. lamarcki, using hierarchical sampling programs. Mar Ecol Prog Ser 116:85-97

Maurer BA (1999) Untangling ecological complexity. University of Chicago Press, Chicago, IL

Meese RJ, Tomich PA (1992) Dots on the rocks - a comparison of percent cover estimations methods. J Exp Mar Biol Ecol 165:59-73

Menconi M, Benedetti-Cecchi L, Cinelli F (1999) Spatial and temporal variability in the distribution of algae and invertebrates on rocky shores in the northwest Mediterranean. J Exp Mar Biol Ecol 233:1-23

Menge BA, Branch GM (2001) Rocky intertidal communities. In: Bertness MD, Gaines SD, Hay ME (eds) Marine community ecology. Sinauer, Sunderland, MA, p 221-251

Mercer WB, Hall AD (1911) The experimental error of field trials. J Agric Sci 4:107-132

Morrisey DJ, Howitt L, Underwood AJ, Stark JS (1992) Spatial variation in soft sediment benthos. Mar Ecol Prog Ser 81: 197-204

Olabarria C, Chapman MG (2001) Habitat-associated variability in survival and growth of three species of microgastropods. J Mar Biol Assoc UK 81:961-966

Palmer MW (1988) Fractal geometry: a tool for describing spatial patterns of plant communities. Vegetatio 75:91-102

Perry NJ, Liebhold AM, Rosenberg MS, Dungan J, Miriti M, Jakomulska A, Cistron-Pousty S (2002) Illustrations and guidelines for selecting statistical methods for quantifying spatial patterns in ecological data. Ecography 25:578-600 Picket S, White P (1985) The ecology of natural disturbances 
and patch dynamics. Academic Press, London

Rossi RE, Mulla DJ, Journel AG, Franz EH (1992) Geostatistical tools for modeling and interpreting ecological spatial dependence. Ecol Monogr 62:277-314

Schneider DC (1994) Quantitative ecology. Spatial and temporal scaling. Academic Press, London

Schoch GC, Dethier MN (1996) Scaling up: the statistical linkage between organismal abundance and geomorphology on rocky intertidal shorelines. J Exp Mar Biol Ecol 201: $37-72$

Searle SR, Casella G, McCulloch GE (1992) Variance component. Wiley, New York

Stark JS, Riddle MJ, Rodney DS (2003) Human impacts in soft-sediments assemblages at Casey Station, East Antarctica: spatial variation, taxonomic resolution and data transformation. Aust Ecol 28:287-304

Terlizzi A, Fraschetti S, Guidetti P, Boero F (2002) The effects of sewage discharge on shallow hard substrate sessile assemblage. Mar Pollut Bull 44:542-550

Terlizzi A, Benedetti-Cecchi L, Bevilacqua S, Fraschetti S, Guidetti P, Anderson MJ (2005) Multivariate and univariate asymmetrical analyses in environmental impact assessment: a case study of Mediterranean subtidal sessile assemblages. Mar Ecol Prog Ser 289:27-42

Thompson RC, Crowe TP, Hawkins SJ (2002) Rocky intertidal communities: past environmental changes, present status and prediction for the next 25 years. Environ Conserv 29: 168-191

Thrush SF, Pridmore RD, Hewitt JE (1994) Impacts on softsediment macrofauna: the effects of spatial variation on temporal trends. Ecol Appl 4:31-41

Thrush SF, Cummings VJ, Dayton PK, Ford R and 11 others (1997a) Matching the outcome of small-scale density manipulation experiments with larger scale patterns: an example of bivalve/adult juvenile interactions. J Exp Mar Biol Ecol 216:153-169

Thrush SF, Schneider DC, Legendre P, Whitlatch RB and 9 others (1997b) Scaling-up from experiments to complex ecological systems: where to next? J Exp Mar Biol Ecol 216:243-254

Underwood AJ (1996) Spatial patterns of variance in density of intertidal populations. In: Floyd RB, Sheppard AW, De Barro PJ (eds) Frontiers of population ecology. CSIRO Publishing, Melbourne, p 369-389

Underwood AJ (1997) Experiments in ecology: their logical

Editorial responsibility: Roger Hughes (Contributing Editor), Bangor, UK design and interpretation using analysis of variances. Cambridge University Press, Cambridge

Underwood AJ, Chapman MG (1996) Scales of spatial patterns of distribution of intertidal invertebrates. Oecologia 107:212-224

Underwood AJ, Chapman MG (1998a) A method for analysing spatial scales of variation in composition of assemblages. Oecologia 117:570-578

Underwood AJ, Chapman MG (1998b) Spatial analyses of intertidal assemblages on sheltered rocky shores. Aust J Ecol 23:138-157

Underwood AJ, Chapman MG (2003) Power, precaution, Type II error and sampling design in assessment of environmental impacts. J Exp Mar Biol Ecol 296:49-70

Underwood AJ, Petraitis PS (1993) Structure of intertidal assemblages in different locations: how can local processes can be compared? In: Rickefs R, Schluter D (eds) Species diversity in ecological communities. University of Chicago Press, Chicago, IL, p 38-51

Underwood AJ, Chapman MG, Connell SD (2000) Observation in ecology: you can't make progress on processes without understanding the patterns. J Exp Mar Biol Ecol 250:97-115

Vanderklift MA, Lavery PS (2000) Patchiness in assemblages of epiphytic macroalgae on Posidonia coriacea at a hierarchy of spatial scales. Mar Ecol Prog Ser 192:127-135

Viejo RM, Åberg P (2003) Temporal and spatial variation in the density of mobile epifauna and grazing damage on the seaweed Ascophyllum nodosum. Mar Biol 142:1229-1241

Warwick RM, Clarke KR (1993) Increased variability as a symptom of stress in marine communities. J Exp Mar Biol Ecol 172:215-226

Winer BJ, Brown DR, Michels KM (1991) Statistical principles in experimental designs, 3rd edn. McGraw-Hill, Sydney

Wootton JT (2001) Local interactions predict large-scale pattern in empirically derived cellular automata. Nature 413: 841-843

Ysebaert T, Herman PMJ (2002) Spatial and temporal variation in benthic macrofauna and relationships with environmental variables in an estuarine, intertidal soft-sediment environment. Mar Ecol Prog Ser 244:105-124

Zajac RN, Lewis RS, Poppe LJ, Twichell DC,Vozarik J, DiGiacomo-Cohen ML (2003) Responses of infaunal populations to benthoscape structure and the potential importance of transition zones. Limnol Oceanogr 48:829-842

Submitted: November 11, 2004; Accepted: January 26, 2005 Proofs received from author(s): June 24, 2005 